\title{
Impact Investing in Sports and Healthcare: problems and trends in measurement
}

\author{
Elena Dedusenko ${ }^{1 *}$ \\ ${ }^{1} \mathrm{PhD}$ in Economics, Department of Hospitality, Tourism and Sport Industry Plekhanov Russian \\ University of Economics, Russia
}

\begin{abstract}
The idea of this paper is to focus on the trends of the impact investing industry worldwide. At this stage of the impact investing development in the international scale such researches are crucial steps for its further growth and use in the different industries. It is essential aim to analyse impact investing potential in the sports and healthcare sectors. In addition, an interesting area of research is the comparison of metrics for evaluating the effectiveness of impact investing and sports and healthcare. The key issues studied include the actual trends and challenges in impact investing system and recommendations for improvement of the impact investing ecosystem.
\end{abstract}

\section{Introduction}

In terms of financing the 2030 Agenda is based on public resources, private, domestic and international sources of finance and new models of sustainable development finance. The Organization for Economic Cooperation (OECD) and Development defines impact investing as a new way of investment activity addressing social and economic challenges, including new models of public and private partnership that can fund, deliver and scale innovative solutions from the ground up [21;22]. In the field of impact investing, we can find many influential stakeholders who provide information, advertising and financial support for development of this type of investment. Thus, the Global Impact Investing Network (GIIN) focuses on decreasing barriers to impact investing so more investors can invest in order to create positive, measurable social and environmental impact alongside a financial return. The GIIN highlights the following key elements of impact investing:

- this type of investment purposefully promotes social and environmental solutions, which distinguishes them from other strategies such as ESG investing, Responsible Investing, and screening strategies;

- impact investing is different from philanthropy because it focuses on a financial return on capital that can range from below market rate to risk-adjusted market rate;

- impact investments can be developed across asset classes;

- the performance of this type of investment is based on the investor's obligation to measure and report on the social and environmental results of the base investment [12-14].

\footnotetext{
*Corresponding author: Dedusenko.EA@ rea.ru, delena7@yandex.ru
} 
Impact investing has its own ecosystem (the supply side, channels of capital, and the demand side) and a certain list of stakeholders. There are the two broad aspects of the impact investment ecosystem: the macro investment climate and the legal support available for investors and social enterprises $[10 ; 16]$. The key regulators should play an important role in the impact investing industry in terms of creating a legal environment, encouraging greater transparency and taking actual steps to help develop the market [1-3]. Given the social and environmental context of impact investing, it will be interesting to see the relationship between this type of investment, the Sustainable Development Goals (SDGs) and sports and healthcare as the sectors with a high level of social and ecological performance.

\section{Materials and methods}

The methodological aspects of this study are based on a comparative analysis of the measurements that characterize the effectiveness of impact investing and their compliance with the Sustainable Development Goals. With increasing interest in this field there is a need to develop the growth of impact investing on measurable principles. The availability of standardized impact metrics linked with the current data will be important for progress on financing the Sustainable Development Goals (SDGs) [22]. To achieve this goal, analytical data and reports from the international organizations and companies such as the OECD, the GIIN, J.P. Morgan Asset Management, Bailard Wealth Management and other organizations have been discussed in this work.

\section{Results}

In the context of classical economics, the investment environment is highly segmented and various segments of the investment market have different features. Currently, the macroeconomic trends demonstrate some political and economic risks that have significant impacts on the investment environment. Given the importance of these trends for impact investing, a complex and long-term approach to investment decision making process will enable potential investors to cash on the perspective opportunities of the impact investing in the countries which demonstrate the gap between supply and demand $[5 ; 6]$.

According to J.P. Morgan Asset Management, the current investment environment and outlook for 2021 have shown the following important principles for investing in 2021:

1) crisis times often lead investors to focus on the short-term decisions, but it is important to rethink investing principles that can be used across market environments;

2) diversification is an important principle of investment in the conditions of turbulence of the external environment. The post-COVID-19 investment world yet to emerge and the experts recommend a well-balanced, diversified approach to investing for long-run strategies;

3) a new trend that investors expect to continue is the use of sustainable investing methods as a multifaceted space allowing investors to contribute to goals beyond just maximizing returns and controlling risk. Additionally, a commitment to sustainable investing methods can allow investors to get ahead of trends in both innovation and regulation $[24$, p.10].

In addition to the economic feasibility of investing, other factors of impact investing process are also important. The GIIN, in its current studies has mentioned that the top reasons for making impact investments all focus on impact. Thus, about of $87 \%$ of respondents consider both 'impact being central to their mission' and 'their commitment as responsible investors' as 'very important' motivations, $81 \%$ believe that impact investing is 
an efficient way to achieve impact goals, and $70 \%$ of investors find the financial attractiveness of impact investing relative to other investment strategies at least somewhat important [13]. By industry, investors expanded their capital allocation most quickly to water, sanitation, and hygiene (WASH), at a Compound Annual Growth Rate (CAGR) of $33 \%$ from 2015 to 2019 and to financial services (excluding microfinance) at a CAGR of $30 \%$ (Table 1).

Table 1. Changes in sector allocations among investors from 2015 to 2019 (in millions of US dollars).

\begin{tabular}{|l|c|c|c|}
\hline \multicolumn{1}{|c|}{ Sector } & $\mathbf{2 0 1 5}$ & $\mathbf{2 0 1 9}$ & CAGR \\
\hline $\begin{array}{l}\text { Water, sanitation, and } \\
\text { hygiene (WASH) }\end{array}$ & 3083 & 9735 & $33 \%$ \\
\hline $\begin{array}{l}\text { Fin services (excl. } \\
\text { microfinance) }\end{array}$ & 5667 & 16432 & $30 \%$ \\
\hline Healthcare & 2405 & 5590 & $23 \%$ \\
\hline Food \& agriculture & 3746 & 8284 & $22 \%$ \\
\hline Total & 51817 & 97483 & $17 \%$ \\
\hline Source: based on [13,p.8]
\end{tabular}

Healthcare is another popular sector; almost $50 \%$ of respondents have some investments in healthcare. Furthermore, healthcare is the third-fastest-growing sector, and $51 \%$ of respondents plan to increase their capital allocations to healthcare over the next five years [13]. Also, according to the survey, investors stay relatively positive about their future performance despite the effects of the pandemic.

\section{Discussion}

At present, the issues related to the system assessment of the integrated impact of investment remain debatable. According to the GIIN research and data on the financial results of impact investments have shown several ways to evaluate financial results (Table 2). The financial evaluation of impact investments affects the internal benchmarking, strategic planning, and communication process. Further research to strengthen knowledge into the potential of impact investing should include analysis of:

- target financial returns across strategies;

- the performance across asset classes;

- fund and investment performance across asset classes at geographic and sector levels;

- the relationship between impact goals, measurement, and financial returns.

In addition, if we are talking about investing in certain activities, such as sports and healthcare, then there may be their own metrics for measurement of the investment effectiveness. These metrics are also important from a methodological point of view. In some studies, for example [4; 7-9], the Social Return on Investment (SROI) as measure of social performance is given. The SROI is a framework for assessing and analyzing the nonmarket economic, social and environmental value of an activity. The SROI value is calculated by dividing the value of outcomes by the value of inputs.

Considering the compliance of certain metrics and measures of performance with the sustainable development goals, it should be noted that some studies have indicated strengthening the contribution of sport and healthcare to Sustainable Development Goal 3 $[11 ; 15 ; 17-20]$. On the other side, major players in the field of impact investing have created their own metrics with compliance with the sustainable development goals. For example, Bailard Wealth Management developed a scoring system called ESG Capture ${ }^{\circledR}$. The combination of its ESG Capture ${ }^{\circledR}$ and additional screening processes crossed closely with individual SDGs [2]. 
Table 2. The existing approaches to assessing the effectiveness of impact investing.

\begin{tabular}{|c|c|}
\hline Authors of methodology & Measures of financial performance \\
\hline $\begin{array}{l}\text { Cambridge Associates (CA) and the } \\
\text { GIIN }\end{array}$ & $\begin{array}{l}\text { - Internal Rate of Return (IRR) net of fees at fund level } \\
\text { (pooled, quartile distributions, by fund size and } \\
\text { geographic focus) } \\
\text { - Total value to paid-in multiples } \\
\text { - Distribution to paid-in multiples }\end{array}$ \\
\hline $\begin{array}{l}\text { Wharton Social Impact Initiative } \\
\text { (WSII) }\end{array}$ & $\begin{array}{l}\text { Pooled gross IRR relative to Russell Microcap/Russell } \\
2000 \text { index and S\&P } 500 \text { index }\end{array}$ \\
\hline McKinsey \& Company & $\begin{array}{l}\text { Gross IRR from exited investments (full and partial exits) } \\
\text { by sector and deal size }\end{array}$ \\
\hline Symbiotics & $\begin{array}{ll}- & \text { Net IRR } \\
\text { - } & \text { Yield } \\
\text { - } & \text { Total expense ratios } \\
\end{array}$ \\
\hline Impact Investing Australia & Gross IRR \\
\hline $\begin{array}{l}\text { EngagedX and the Social } \\
\text { Investment Research Council }\end{array}$ & $\begin{array}{ll}- & \text { Gross IRR } \\
\text { - } & \text { Write-off ratio }\end{array}$ \\
\hline Boston Consulting Group (BCG) & $\begin{array}{ll}- & \text { Gross IRR } \\
\text { - } & \text { Write-off ratio } \\
\end{array}$ \\
\hline
\end{tabular}

\section{Conclusion}

Currently, in the field of impact investment, there are favorable conditions both for further research of this responsible and valuable type of investment, and for improving the methodological aspects of the effectiveness evaluation of impact investing. Also, the compliance of the economic and non-economic efficiency of the investments with the SDGs has shown the high level of importance. In addition, the issue of creating a unified system for evaluating the effectiveness of impact investing and using this methodology on an international scale remains debatable.

\section{References}

1. Barber, B.M., Morse, A., Yasuda, A. Impact investing. Journal of Financial Economics. 139(1), p. 162-185 (2021)

2. Bailard Wealth Management. Social Impact Report Sustainable, Responsible and Impact Investing. (2020)

3. Caseau, C., Grolleau, G. Impact Investing: Killing Two Birds with One Stone? Financial Analysts Journal. 76(4), p. 40-52 (2020)

4. Dedusenko, E.A. Sporting mega-events as catalysts for sustainability and tourism development in Russia. Journal of Environmental Management and Tourism. 10(2), p. 346-353 DOI: 10.14505/jemt.v10.2(34).08 (2019)

5. Dedusenko, E.A. Impact investing trends in Russia and tourism. Journal of Environmental Management and Tourism. 8(8), p. 1474-1481 DOI: 10.14505/jemt.v8.8(24).03 (2017)

6. Dedusenko, E.A. Hospitality investment environment in Russia. Journal of Environmental Management and Tourism. 8(2), p. 291-300 DOI: 10.14505/jemt.v8.2(18).02 (2017) 
7. Davies L., Taylor P., Ramchandani G., Christy E. Social Return on Investment in Sport: A participation wide model for England (2016)

8. Edwards, M.R. The Olympic Effect: Employee Reactions to Their Employer's Sponsorship of a High-Profile Global Sporting Event. Human Resource Management. 55(4), p. 721-740 (2016)

9. Goryakin, Y., Aldea, A., Lerouge, A., (...), Devaux, M., Cecchini, M. Promoting sport and physical activity in Italy: A costeffectiveness analysis of seven innovative public health policies. Annali di Igiene. 31(6), p. 614-625 (2019)

10. Gusarova, S., Gusarov, I., Smeretchinskiy, M.Sustainable future growth on the base of impact investing in BRICS countries. E3S Web of Conferences 208,0304 (2020)

11. Grix, J., Houlihan, B. Sports mega-events as part of a nation's soft power strategy: The cases of Germany (2006) and the UK (2012). British Journal of Politics and International Relations. 16(4), p. 572-596 (2014)

12. Global Impact Investing Network's. Core Characteristics of Impact Investing. Available at: https://thegiin.org/characteristics

13. Global Impact Investing Network's. Annual Impact Investor Survey. Available at: https://thegiin.org (2020)

14. Global Impact Investing Network's perspectives. Evidence on the Financial Performance of Impact Investments. Available at:

https://thegiin.org/research/publication/financial-performance (2017)

15. Hegeduš, I., Gregoric, M., Skryl, T.V., Romanyuk, A.V., Gureeva, E.A. Sports and recreational tourism of Koprivnica Krizevci county in Republic of Croatia. Journal of Environmental Management and Tourism 8(8), p. 1595-1603 DOI: 10.14505/jemt.v8.8(24).16 (2017)

16. Kim, M.J., Hall, C.M. Investment crowdfunding in the visitor economy: the roles of venture quality, uncertainty, and funding amount. Current Issues in Tourism. 23(20), p. 2533-2554 (2020)

17. Koronios, K., Dimitropoulos. P. Examining Sponsorship's Effectiveness over the Internet: A Conceptual Framework for Researchers and Practitioners. International Journal of Innovation and Technology Management. 17(4), 2050027 (2020)

18. Lindsey I., Chapma T. Enhancing the Contribution of Sport to the Sustainable Development Goals. Secretariat (2017)

19. Melovic, B., Rogic, S., Smolovic, J.C., Dudic, B., Gregus, M. The impact of sport sponsorship perceptions and attitudes on purchasing decision of fans as consumersrelevance for promotion of corporate social responsibility and sustainable practices. Sustainability (Switzerland). 11(22),6389 (2019)

20. Ofosu, A., Kotey, R.A. Does sports betting affect investment behaviour? Evidence from Ghanaian sports betting participants. Journal of Gambling Issues. 43, p. 61-83 (2019)

21. OECD. Social Impact Investment. Available at: http://www.oecd.org/social/socialimpact-investment.htm

22. OECD. Social Impact Investment 2019: The Impact Imperative for Sustainable Development, Paris (2019). https://doi.org/10.1787/9789264311299-en

23. Skryl, T.V. Evaluating the risks of public private partnerships for projects in the health care system. International Journal of Advanced Science and Technology. 28 (8 Special Issue), p. 560-567 (2019) 
24. The Investment Outlook for 2021. J.P. Morgan Asset Management (2020) https://am.jpmorgan.com/us/en/asset-management/institutional/insights/marketinsights/investment-outlook/]. 